\title{
AN ESTIMATION OF THE HEPATIC BLOOD FLOW AND SPLANCHNIC OXYGEN CONSUMPTION IN HEART FAILURE ${ }^{1}$
}

\author{
By J. D. MYERS AND J. B. HICKAM 2
}

(From the Department of Medicine, Duke University School of Medicine, Durham, N. C.)

(Received for publication April 10, 1948)

That the circulation of the liver is disturbed in heart failure is well known to every clinician. A tender, enlarged liver is a frequent and at times the only evident manifestation of cardiac failure. The disturbances in the circulation leading to hepatic enlargement have been difficult to investigate because of the lack of methods to measure hepatic blood flow and cardiac output in patients with congestive heart failure. The recent introduction of the procedure of catheterization of the hepatic veins has provided means for the estimation of hepatic blood flow and splanchnic oxygen consumption of $\operatorname{man}^{3}(1,2,3)$. The cardiac output can be measured in the same study by right heart catheterization. These advances in methodology have made possible investigation of the effects of alteration of the cardiac output on the circulation of the liver.

When the cardiac output is inadequate to meet the total metabolic needs of the body, the various viscera do not participate equally in the reduction of blood supply. This has been shown clearly for the kidney by Merrill (4) where a 50 per cent reduction in cardiac output may be accompanied by as much as an 80 per cent reduction in renal blood flow. Thus, under circumstances where the total cardiac output is below normal, the blood flow of each viscus in turn must be assayed. Most patients with symptoms and signs of chronic heart failure, which prove to be persistent at rest and on a normal diet, have subnormal cardiac outputs

\footnotetext{
1 This work was supported by grants from the Life Insurance Medical Research Fund and the Anna $H$. Hanes Fund of Duke University.

2 Holder of American College of Physicians Clinical Fellowship, 1946-1947.

3 The splanchnic area as used in this paper constitutes the liver plus those viscera drained by the portal vein. The splanchnic blood flow is equal to the total hepatic blood flow. The splanchnic oxygen consumption, however, equals the hepatic oxygen consumption plus the oxygen consumption of the various portal viscera.
}

(5) and therefore provide clinical material for study of the effect of an inadequate cardiac output on hepatic blood flow. This report deals with the data which have been collected on a group of 13 of such patients with heart failure of various degrees and of various etiologies. The group by selection contains no patients, such as those with severe anemia or thyrotoxicosis, in whom heart failure develops in the face of a normal or supernormal cardiac output. Studies of the latter type of patient will be reported in a future communication. The results in the patients with cardiac failure are compared with the data on 14 subjects without any or significant disease who were studied under similar experimental conditions. Part of these control data have been presented in a previous publication (3); control cases studied since then have yielded concordant results.

\section{METHODS}

The patients with cardiac failure had all fasted for a period of 12 hours or longer prior to the study. Effort was made throughout the procedure to avoid reactions of apprehension on the part of the patients. In a few individuals phenobarbital $0.1 \mathrm{gm}$. was administered orally about one hour before the beginning of the study. An estimate was made in each subject of the amount of anxiety produced in response to the entire procedure.

The intravenous catheter was introduced as described in a previous publication (3). In most instances an hepatic vein, usually one of the right veins, was catheterized first for the estimation of hepatic blood flow and splanchnic oxygen consumption; upon the completion of these measurements the catheter was withdrawn into the right heart for the collection of the mixed venous blood sample for determination of the cardiac output. The mixed venous sample was obtained in most instances from the pulmonary artery, but in some, for technical reasons, blood from the right ventricle or right atrium near the tricuspid valve was used. In a few patients the cardiac output was measured before the determination of the liver blood flow rather than following it.

The oxygen content of the blood samples was determined by the method of Van Slyke and Neill. Analyses were performed in duplicate and were required to check 
within 0.1 volume per cent. The oxygen and carbon dioxide contents of the expired air were measured by the method of Haldane. Atrial pressures were recorded by a sensitive Hamilton manometer and mean pressures determined by planimetric integration, the point of zero reference being $5 \mathrm{~cm}$. posterior to the fourth left costochondral junction. Peripheral venous pressures, when measured, were obtained using a saline manometer. Arterial blood samples were withdrawn from a femoral artery through an inlying needle.

The liver blood flow was estimated by the bromsulphalein method of Bradley $e t$ al. $(2,3)$. The bromsulphalein in the serum was determined by means of a Lumetron photelometer at a wave length of $575 \mathrm{~m} \mu$. As a rule, 1 ml. of serum was diluted with $10 \mathrm{ml}$. of $1 / 50 \mathrm{~N}$ sodium hydroxide in 0.9 per cent sodium chloride solution. The color developed under these circumstances is stable for at least one hour. All determinations were made in duplicate. Care was exercised to prevent hemolysis of blood samples prior to the separation of their sera.
Plasma volume determinations were done on every patient upon the completion of the measurements of hepatic blood flow. The ten-minute Evans blue ( $T$ 1824) technique was used. The plasma volume is utilized in calculating hepatic blood flow in the presence of a rising or falling arterial serum concentration of bromsulphalein (2). No data are included if the bromsulphalein concentration was changing at a rate exceeding $0.0002 \mathrm{mgm}$. per $\mathrm{ml}$. of serum per min.

\section{RESULTS}

The data on the 13 patients with various kinds of heart failure are given in Tables I and II. Some sets of data are incomplete in one or more items for technical reasons. Most of the patients had only minor or no anxiety during the procedure. Edema and serous effusions were disregarded in the determination of body weight for

TABLE I

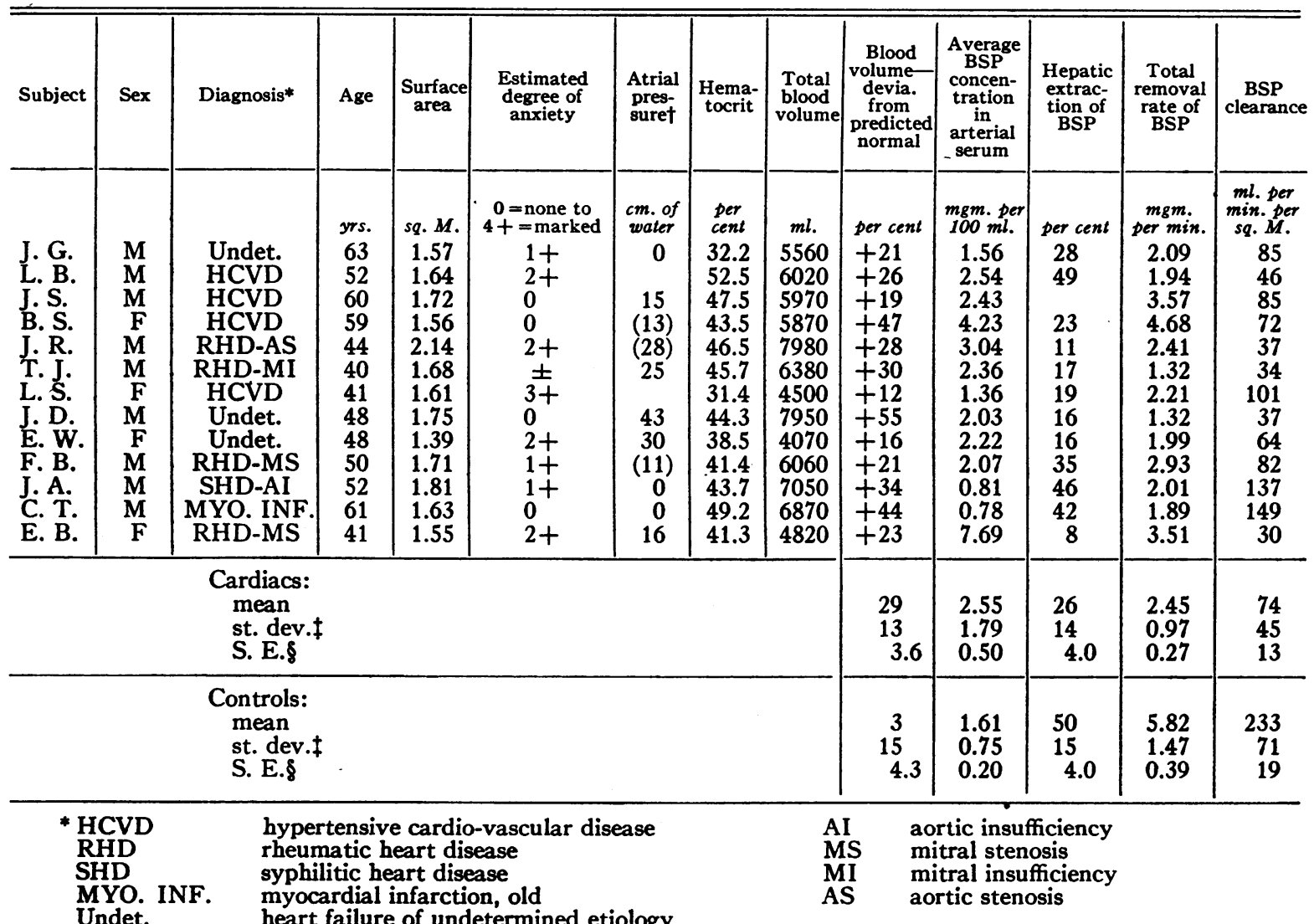

† Figures in parentheses are antecubital venous pressures.

$\ddagger$ standard deviation, $s=\sqrt{\frac{\Sigma X^{2}-\frac{(\Sigma X)^{2}}{n}}{n-1}}$.

$\$$ standard error $=\frac{s}{\sqrt{n}}$. 
TABLE II

\begin{tabular}{|c|c|c|c|c|c|c|c|c|c|c|c|}
\hline Subject & $\begin{array}{c}\text { Oxygen } \\
\text { con- } \\
\text { sumption }\end{array}$ & $\begin{array}{c}\text { Meta- } \\
\text { bolic } \\
\text { rate- } \\
\text { devia. } \\
\text { from } \\
\text { normal } \\
\text { basal }\end{array}$ & $\begin{array}{c}\text { Oxygen } \\
\text { satur. of } \\
\text { arterial } \\
\text { blood }\end{array}$ & $\begin{array}{c}\text { Oxygen } \\
\text { content } \\
\text { of } \\
\text { arterial } \\
\text { blood }\end{array}$ & $\begin{array}{l}\text { Arterial- } \\
\text { mixed } \\
\text { venous } \\
\text { oxygen } \\
\text { diff. }\end{array}$ & $\begin{array}{l}\text { Arterial- } \\
\text { hepatic } \\
\text { venous } \\
\text { oxygen } \\
\text { diff. }\end{array}$ & $\underset{\text { index }}{\text { Cardiac }}$ & $\begin{array}{c}\text { Hepatic } \\
\text { blood } \\
\text { flow }\end{array}$ & $\begin{array}{l}\text { Hepatic } \\
\text { blood flow } \\
\text { as percent. } \\
\text { of cardiac } \\
\text { output }\end{array}$ & $\begin{array}{c}\text { Splanchnic } \\
\text { oxygen } \\
\text { consump. }\end{array}$ & $\begin{array}{c}\text { Splanchnic } \\
\text { oxygen } \\
\text { consump. } \\
\text { as percent. } \\
\text { of total } \\
\text { oxygen } \\
\text { consump. }\end{array}$ \\
\hline $\begin{array}{l}\text { J. G. } \\
\text { L. B. } \\
\text { J. S. } \\
\text { B. S. } \\
\text { J. R. } \\
\text { T. J. } \\
\text { L. S. } \\
\text { J. D. } \\
\text { E. W. } \\
\text { F. B. } \\
\text { J. A. } \\
\text { C. T. } \\
\text { E. B. }\end{array}$ & $\begin{array}{c}\text { ml. per } \\
\text { min. per } \\
\text { sq. M. } \\
166 \\
185 \\
155 \\
160 \\
206 \\
161 \\
124 \\
117 \\
162 \\
110 \\
140 \\
148 \\
131\end{array}$ & $\begin{array}{l}\text { per cent } \\
+33 \\
+44 \\
+25 \\
+36 \\
+56 \\
+22 \\
+2 \\
+13 \\
+34 \\
-14 \\
+9 \\
+19 \\
+7\end{array}$ & $\begin{array}{c}\text { per cent } \\
88 \\
90 \\
97 \\
89 \\
92 \\
89 \\
92 \\
89 \\
96 \\
96 \\
96 \\
97 \\
92\end{array}$ & $\begin{array}{c}\text { vol. } \\
\text { per cent } \\
12.0 \\
19.6 \\
19.1 \\
16.9 \\
16.7 \\
16.1 \\
9.6 \\
16.0 \\
14.9 \\
18.0 \\
17.0 \\
19.7 \\
17.6\end{array}$ & $\begin{array}{c}\text { vol. } \\
\text { per cent } \\
6.1 \\
8.4 \\
10.2 \\
8.2 \\
7.7 \\
7.7 \\
5.9 \\
8.0 \\
6.5 \\
7.2 \\
5.3 \\
5.5 \\
6.0\end{array}$ & $\begin{array}{c}\text { ool. } \\
\text { per cent } \\
8.8 \\
12.8 \\
11.0 \\
9.1 \\
9.6 \\
9.2 \\
5.9 \\
8.8 \\
7.7 \\
8.0 \\
6.2 \\
5.5 \\
6.6\end{array}$ & $\begin{array}{c}\text { liters } \\
\text { per min. } \\
\text { per sq. } \boldsymbol{M} \text {. } \\
2.7 \\
2.2 \\
1.5 \\
2.0 \\
2.7 \\
2.1 \\
2.1 \\
1.5 \\
2.5 \\
1.5 \\
2.6 \\
2.7 \\
2.2\end{array}$ & $\begin{array}{c}\text { ml. per } \\
\text { min. per } \\
\text { sq. M. } \\
460 \\
200 \\
\\
530 \\
680 \\
370 \\
800 \\
420 \\
650 \\
390 \\
540 \\
680 \\
700\end{array}$ & $\begin{array}{c}\text { per cent } \\
17 \\
9 \\
\\
27 \\
25 \\
18 \\
38 \\
29 \\
26 \\
25 \\
21 \\
25 \\
32\end{array}$ & $\begin{array}{c}\text { ml. per } \\
\text { min. per } \\
\text { sq. M. } \\
41 \\
26 \\
48 \\
48 \\
65 \\
34 \\
47 \\
37 \\
50 \\
31 \\
33 \\
37 \\
46\end{array}$ & $\begin{array}{l}\text { per cent } \\
25 \\
14 \\
30 \\
32 \\
21 \\
38 \\
32 \\
31 \\
29 \\
24 \\
25 \\
35\end{array}$ \\
\hline $\begin{array}{l}\text { Cardiacs: } \\
\text { mean } \\
\text { st. dev.* } \\
\text { S. E. } \dagger\end{array}$ & $\begin{array}{c}151 \\
27 \\
7.5\end{array}$ & $\begin{array}{l}20 \\
21 \\
5.8\end{array}$ & & & $\begin{array}{l}7.1 \\
1.4 \\
0.4\end{array}$ & $\begin{array}{l}8.4 \\
2.0 \\
0.6\end{array}$ & $\begin{array}{l}2.2 \\
0.5 \\
0.14\end{array}$ & $\begin{array}{r}535 \\
170 \\
49\end{array}$ & $\begin{array}{l}24 \\
7 \\
2.0\end{array}$ & $\begin{array}{l}41 \\
11 \\
3.2\end{array}$ & $\begin{array}{l}28 \\
7 \\
2.0\end{array}$ \\
\hline $\begin{array}{l}\text { Controls: } \\
\text { mean } \\
\text { st. dev.* } \\
\text { S. E. } \dagger\end{array}$ & $\begin{array}{c}153 \\
16 \\
5.3\end{array}$ & $\begin{array}{l}13 \\
10 \\
3.3\end{array}$ & & & $\begin{array}{l}3.9 \\
0.5 \\
0.2\end{array}$ & $\begin{array}{l}4.5 \\
0.8 \\
0.2\end{array}$ & $\begin{array}{l}4.1 \\
0.5 \\
0.17\end{array}$ & $\begin{array}{r}850 \\
170 \\
45\end{array}$ & $\begin{array}{c}20 \\
4 \\
1.3\end{array}$ & $\begin{array}{c}38 \\
10 \\
2.9\end{array}$ & $\begin{array}{l}24 \\
8 \\
2.7\end{array}$ \\
\hline
\end{tabular}

* standard deviation.

the estimation of surface area. However, only two patients (L. S. and J. D.) had edema or effusions of such degree as might significantly affect calculations.

As compared to normal individuals $(2,3)$, relatively higher concentrations of bromsulphalein were obtained in cardiacs from a given dose of the dye per minute. The 13 patients obtained a mean concentration in arterial serum of $2.55 \pm$ 1.79 mgm. ${ }^{4}$ per $100 \mathrm{ml}$. from an average infusion rate of $2.5 \pm 0.97 \mathrm{mgm}$. per min. The 12 control subjects showed a mean arterial concentration of $1.61 \pm 0.75 \mathrm{mgm}$. per $100 \mathrm{ml}$. from an average infusion rate of $5.82 \pm 1.47 \mathrm{mgm}$. per min. The percentage extraction of bromsulphalein ( [arterial serum concentration - hepatic venous serum concentration] $\div$ [arterial serum concentration]) varied widely but in general was again subnormal in the patients with heart failure, they

4 Throughout this paper in the expression of \pm values, the standard deviation, $s$, is used, where

$$
s=\sqrt{\frac{\Sigma X^{2}-\frac{(\Sigma X)^{2}}{n}}{n-1}}
$$

† standard error.

averaging 26 per cent extraction as compared to 50 per cent for the controls. As the percentage extraction varies inversely with the arterial concentration, the control subjects with their lower average arterial concentration of bromsulphalein would be expected to have a higher percentage of extraction. However, it seems that the difference in arterial concentration does nat account for the difference in extraction between the controls and the cardiacs. From our data, the control subjects at an arterial concentration of $2.55 \mathrm{mgm}$. per 100 $\mathrm{ml}$. (the average arterial concentration for the group with heart failure) would have a predicted extraction of 37 per cent. This is to be compared with the 26 per cent extraction found in the heart failure group at that average arterial concentration.

The data on the removal of bromsulphalein by the liver of heart failure, in comparison with the normal liver, are better expressed in terms of bromsulphalein clearance ([total removal rate of BSP in mgm. per min. per sq. M.] $\div$ [concentration of BSP in mgm. per $\mathrm{ml}$. of arterial serum] $=\mathrm{ml}$. of arterial serum cleared completely of 
BSP per min. per sq. M.). In our series of 14 subjects without significant disease the bromsulphalein clearance ranged from 152 to $365 \mathrm{ml}$. per minute per sq. M. with a mean of $233 \pm 71 \mathrm{ml}$. The cardiac patients gave clearance of from 30 to $149 \mathrm{ml}$. per min. per sq. M. for a mean of 74 $\pm 45 \mathrm{ml}$.

It has been shown (2) that bromsulphalein in the blood stream is protein-bound and that dye will be lost into the urine in the presence of proteinuria. Only three of the present series of cardiac patients (B. S., J. R., and J. D.) had proteinuria by the usual qualitative tests at the time of the measurement of hepatic blood flows. These proteinurias were all of moderate degree and it does not seem that the amount of dye lost into the urine would seriously affect the determinations.

Oxygen consumptions in the group with cardiac failure ranged from 110 to $206 \mathrm{ml}$. per min. per sq. M. of body surface. The corresponding metabolic rates varied between minus 13 and plus 56 per cent of the normal basal with a mean of plus 20 per cent. In this respect the patients with cardiac failure did not differ significantly from the controls who had a mean metabolic rate under the conditions of this study of plus 13 per cent of the normal basal.

None of the patients demonstrated a marked degree of unsaturation of the arterial blood for oxygen. The patients with more severe degrees of heart failure, however, did have moderate unsaturation.

The values for hematocrit and oxygen content of arterial blood in Tables I and II show that only two patients (J. G. and L. S.) had significant anemia. It is unlikely that the degree of anemia in subject J. G. played any great part in altering his circulatory measurements, as Brannon et al. (6) have found that depression of the hemoglobin to below $7 \mathrm{~g}$. per $100 \mathrm{ml}$. is necessary before one gets a significant effect on total cardiac output. In the case of L. S., however, it cannot be assumed that her anemia may not have affected the data. It is noted that L. S. had the highest hepatic blood flow of any patient with heart failure. It has been observed ( 7 ) that severe degrees of anemia in the absence of heart failure are associated with elevated hepatic blood flows, which in general are proportionate to the elevation in total cardiac outputs due to the anemia.

All patients with cardiac failure had elevated arterial-mixed venous oxygen differences, the values ranging from 5.3 to 10.2 volumes per cent and the mean being $7.1 \pm 1.4$ volumes per cent. The control subjects by comparison gave differences of from 3.3 to 4.7 volumes per cent with a mean of $3.9 \pm 0.5$ volumes per cent. Arterialhepatic venous oxygen differences corresponded, the cardiacs showing elevated values varying from 5.5 to 12.8 volumes per cent for a mean of $8.4 \pm$ 2.0 volumes per cent. The control group had differences of from 3.8 to 5.8 volumes per cent with a mean of $4.5 \pm 0.8$ volumes per cent. Thus all the patients with cardiac failure, with the exception of one (C. T.) who had only mild failure, showed decidedly elevated arterial-hepatic venous differences. In the cardiacs, as in normal persons (3), the arterial-hepatic venous difference in general exceeds the arterial-mixed venous difference by a small amount.

Every patient with heart failure had a subnormal cardiac index (cardiac output in liters per min. per sq. M. of body surface), particularly when it is remembered that the nature and duration of the circulatory measurements reported here tend to increase the circulation somewhat above the basal. The control group had cardiac indices between 3.3 and 4.9 , the patients with heart failure indices from 1.5 to 2.7 . The means of these determinations are for the controls $4.1 \pm 0.5$, and for the cardiacs $2.2 \pm 0.5$.

The estimated hepatic blood flows vary over a considerable range in both the control and heart failure groups. This is probably explainable, at least in part, when it is remembered that the flow through only one portion of the liver is being determined, and that the flows as estimated from several areas of the same liver under the same conditions may show considerable variation (2). Furthermore, several of the patients in the heart failure group had low extraction percentages for bromsulphalein. Under this circumstance, the usual technical errors in measuring the dye concentrations in arterial and hepatic venous bloods have a considerably greater influence on the calculated hepatic blood flow. The hepatic blood flows for the patients with heart failure ranged from 200 to $800 \mathrm{ml}$. per min. per sq. M. of body 
surface; the controls gave values of from 600 to $1160 \mathrm{ml}$. per min. per sq. M. The average values for the cardiacs are $535 \pm 170 \mathrm{ml}$. and for the controls $850 \pm 170 \mathrm{ml}$. This overall difference is statistically significant $(p<0.01)$. When the values for cardiac output and hepatic blood flow in each patient are correlated, it is found that, in both the control group and the series with heart failure, the hepatic blood flow represents a fairly constant percentage of the cardiac output. Among the cardiacs the hepatic blood flow made up on the average $24 \pm 7$ per cent of the cardiac output; in the controls it comprised $20 \pm 4$ per cent. Three patients with heart failure show considerable disproportion between the two values. Patient L. B., who had severe heart failure at the time of study, had a very low hepatic blood flow and at the same time an extreme hepatic arteriovenous oxygen difference. He is the only patient in our experience to manifest a much more marked reduction in liver blood flow than in cardiac output. Whether this does occur with any frequency in severe heart failure can only be told by the study of more patients. Patient L. S., with an arterial oxygen content of only 9.6 volumes per cent, had a high liver blood flow in proportion to her cardiac output. One can only conjecture concerning the effect of her considerable anemia in explaining this discrepancy. Patient E. B. also had an hepatic blood flow which was proportionately large for her cardiac output. E. B. had a chronically enlarged liver, and palpable spleen and, as can be seen in Table I, a marked retention of bromsulphalein, $7.69 \mathrm{mg}$. per $100 \mathrm{ml}$. of arterial serum from a moderate dose of $3.51 \mathrm{mg}$. of dye per minute. At her extraction percentage of bromsulphalein of only 8 per cent, the measurement of liver blood flow is subject to considerable error. Thus the figure of $700 \mathrm{ml}$. per min. per sq. M. is open to question. It seems likely that E. B. had chronic liver disease out of proportion to that usually encountered in congestive heart failure; possibly this liver disease may have locally affected hepatic blood flow (8). In only one other patient in the series, (J. D.), were there clinical indications of the existence of liver disease which was out of proportion to the degree and duration of the cardiac decompensation.

The splanchnic oxygen consumption (hepatic blood flow $\times$ hepatic $A-V$ oxygen difference) in the patients with heart failure ranged from 26 to $65 \mathrm{ml}$. per min. per sq. M. as compared with the control range of 26 to $53 \mathrm{ml}$. The corresponding mean values are, for the cardiacs, $41 \pm 11 \mathrm{ml}$. and, for the controls, $38 \pm 10 \mathrm{ml}$. When the splanchnic oxygen consumptions for the two groups are expressed as percentages of the respective total oxygen consumptions, again essentially identical values are obtained, $28 \pm 7$ per cent for the cardiacs and $24 \pm 8$ per cent for the controls.

\section{DISCUSSION}

Before discussing what implications can be drawn from the above data, several precautions must be sounded in connection with the interpretation of such data. Firstly, circulatory measurements as have been reported in this paper have such inherent variations as to show quite wide discrepancies even among similar individuals (9). Secondly, any measurements made by the procedure of catheterization of one of several hepatic veins are measurements by sampling and again considerable variation among similar subjects is to be expected. Lastly, our studies by their very nature could not be performed under consistently basal conditions, the element of anxiety to the procedure being particularly variable. It must be stressed therefore, that comparison of any one case with another might well lead to erroneous conclusions, and that only groups of cases should be compared. Thus the mean values reported here are the pertinent figures.

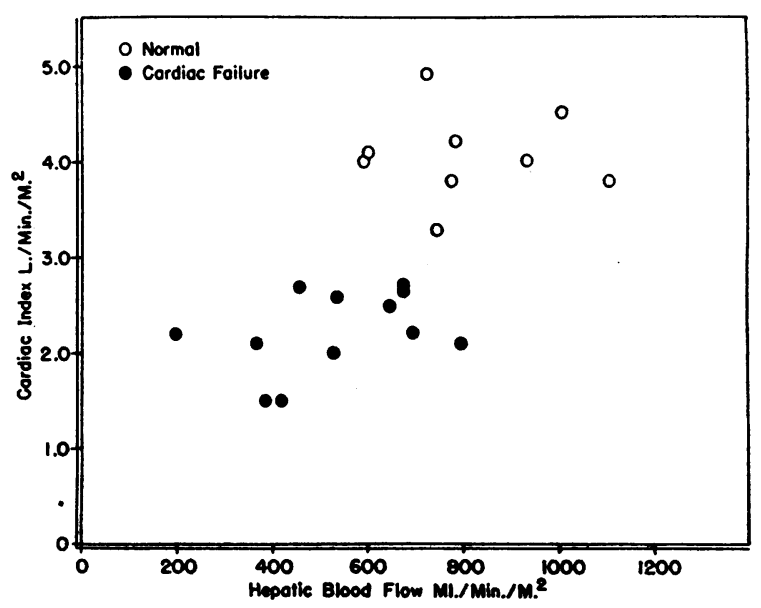

Fig. 1. The Relationship of Hepatic Blood Flow to Cardiac Output in Control Subjects and Patients with Heart Failure 


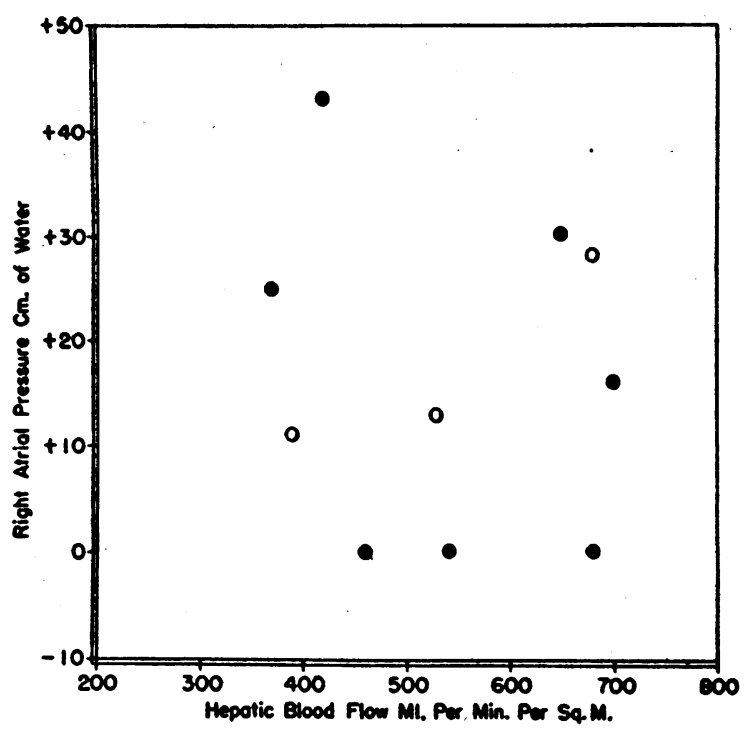

Fig. 2. Hepatic Blood Flow at Various levels of Right Atrial Pressures (Black Dots) and Peripheral. Venous Pressure (Open Circles)

The above data indicate that in cardiac failure there is a decrease in hepatic blood flow, and that this decrease is roughly proportionate to the decrease in total cardiac output (Figure 1). Mechanisms by which this decrease in flow might be brought about are (a) a decreased inflow of blood due to a decrease in total cardiac output, (b) vasoconstriction of the afferent vessels to the liver, similar to that presumed for the kidney in heart failure (4), (c) an increased resistance in the hepatic capillary bed as from edema or other pathologic changes in the liver itself, and $(d)$ impairment to outflow of blood from the liver because of an elevation of hepatic venous pressure as a part of the general elevation of venous pressure found in heart failure. The finding that the mean hepatic blood flow in heart failure expressed as a percentage of the total cardiac output, $24 \pm 7$ per cent, is the same as for the control subjects, $20 \pm 4$ per cent, is of particular significance in that it indicates that there is no selective reduction of the liver blood flow. Thus possibilities (b) and (c) above are eliminated as accounting, by themselves at least, for the reduced flow. Examination of Tables I and II and Figure 2 shows that there is poor correlation between the level of hepatic blood flow and the corresponding right atrial or antecubital venous pressure. For example, patient E. W. had an hepatic blood flow within the lower normal range, $650 \mathrm{ml}$. per min. per sq. M., in the presence of a right atrial pressure of $30 \mathrm{~cm}$. of water. Several patients do show reduced hepatic blood flows in conjunction with elevated pressures. However, both phenomena may be parallel manifestations of severe heart failure and are not necessarily directly interrelated. It seems, then, that the liver blood flow in heart failure is governed, in large part at least, by the level of the cardiac output. The liver receives its usual percentage of the total output, in this respect differing strikingly from the kidney which undergoes a marked and disproportionate reduction in blood flow.

It has been considered that the so-called central necrosis of liver lobules found in heart failure is a manifestation of an increased hepatic venous pressure. The finding of similar lesions in severe anemia and anoxemia (10) without elevation of venous pressure throws doubt on the above correlation. Our finding of a marked unsaturation of hepatic venous blood in cardiac failure is in agreement with the hypothesis that central necrosis may be related to a low oxygen concentration in the blood bathing those liver cells which lie farthest from the afferent blood supply.

The individual in heart failure with a reduced cardiac output maintains a normal body oxygen consumption by an increased extraction of oxygen from that blood supplied to the various viscera, that is, by an increased arterial-mixed venous oxygen difference. This is demonstrated for our

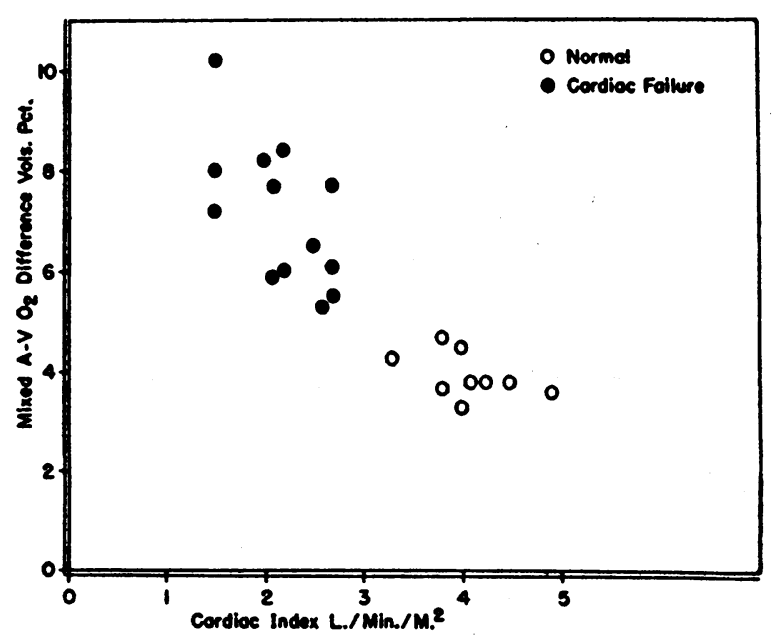

Fig. 3. Relationship of Mixed Arterio-Venous Oxygen Difference to the Cardiac Output in Control Subjects and Patients with Heart Failure 
group of patients with cardiac failure in Figure 3. The moderate reduction in blood supply which the liver suffers in heart failure is accompanied by a similar compensatory increase in extraction of oxygen from that blood supplied to it (Figure 4). This increase in arterial-hepatic venous oxygen difference allows the body to maintain, under conditions of rest and fasting, a normal splanchnic oxygen consumption. It seems reasonable, under the conditions of our study, that the splanchnic oxygen consumption, which is the oxygen

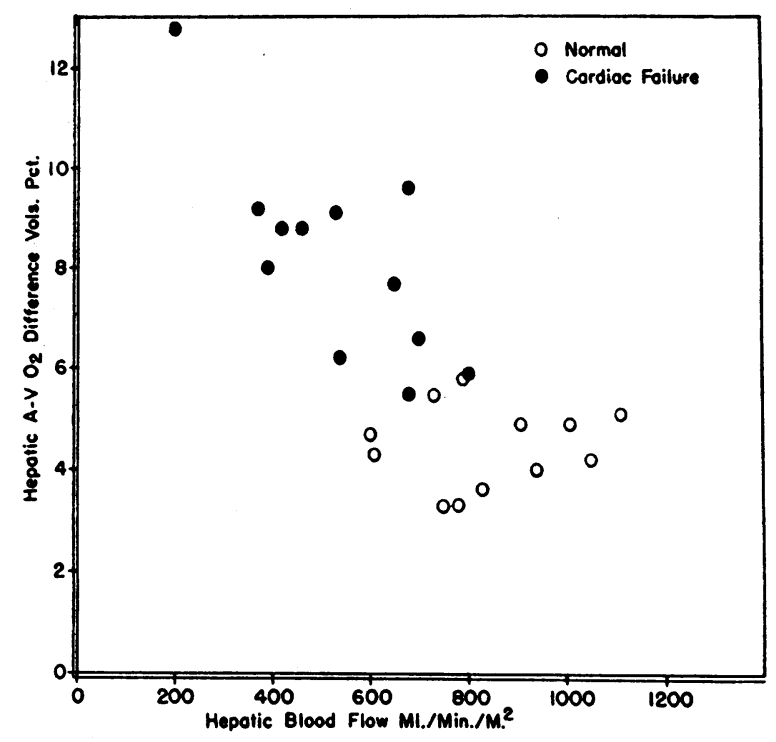

Fig. 4. Relationship of Hepatic Arterio-Venous Oxygen Difference to Hepatic Blood Flow in Control Subjects and Patients with Cardiac Failure

consumption of the gut, pancreas and spleen as well as the liver, is reflective of the true hepatic oxygen consumption. The finding of a normal splanchnic oxygen consumption, then, is in agreement with the clinical observations that the liver of heart failure maintains most of its function quite well, e.g., the formation of plasma proteins. One awaits with interest, however, studies as to the effects of various stresses, such as exercise and the intake of foodstuffs, on the liver blood flow and oxygen consumption. Several of our patients (e.g., J. S., J. B.), with cardiac failure had such large arterial-hepatic venous oxygen differences that little further increase in splanchnic oxygen consumption could be accomplished without an increase in blood flow. Since many in- dividuals with severe heart failure are incapable of an increase in cardiac output so as to be able to augment hepatic blood flow (11), an increase in the latter could only be provided, if at all, by a diversion of blood from some other portion of the body. The liver of heart failure, then, when under stress, might well find its supply of oxygen and other metabolites inadequate to meet normal metabolic demands.

\section{SUM MARY}

1. The hepatic blood flow in a group of 13 patients with cardiac failure, as estimated by the bromsulphalein method, varied from 200 to 800 $\mathrm{ml}$. per min. per sq. M. of body surface with a mean of $535 \pm 170 \mathrm{ml}$. The hepatic blood flows in a group of 14 controls studied under similar circumstances ranged between 600 to $1160 \mathrm{ml}$. for a mean of $850 \pm 170 \mathrm{ml}$. Statistical analysis shows the difference between the means of the two groups to be highly significant.

2. The mean cardiac indices for the two groups were 2.2 for the cardiacs and 4.1 for the controls. The hepatic blood flows expressed as percentages of the total cardiac outputs averaged 24 per cent for the cardiacs and 20 per cent for the controls.

3. The arterial-hepatic venous oxygen differences for the patients with heart failure varied from 5.5 to 12.8 volumes per cent, as compared to a range of 3.3 to 5.8 volumes per cent in the controls. Mean values were 8.4 volumes per cent for the cardiacs and 4.5 volumes per cent for the controls.

4. The average splanchnic oxygen consumption in heart failure was $41 \mathrm{ml}$. and for the controls 38 $\mathrm{ml}$. per min. per sq. M. of body surface. These values represent 28 per cent and 24 per cent, respectively, of the total oxygen consumption.

\section{CONCLUSIONS}

1. The hepatic blood flow in cardiac failure is moderately reduced, and in proportion to the reduction in total cardiac output.

2. This reduction in liver blood flow is compensated by an increase in arterial-hepatic venous oxygen difference so as to provide, under conditions of rest and fasting, a normal splanchnic oxygen consumption. 


\section{ACKNOWLEDGMENT}

Technical assistance was provided by Miss Leila Holmes, Mrs. Juanita M. Clontz, Miss Regina Frayser, and Miss Frances Harris.

\section{BIBLIOGRAPHY}

1. Warren, J. V., and Brannon, E. S., A method of obtaining blood samples directly from the hepatic vein in man. Proc. Soc. Exper. Biol. \& Med., 1944, 55, 144.

2. Bradley, S. E., Ingelfinger, F. J., Bradley, G. P., and Curry, J. J., Estimation of hepatic blood flow in man. J. Clin. Invest., 1945, 24, 890.

3. Myers, J. D., The hepatic blood flow and splanchnic oxygen consumption of man-their estimation from urea production or bromsulphalein excretion during catheterization of the hepatic veins. J. Clin. Invest., 1947, 26, 1130.

4. Merrill, A. J., Edema and decreased renal blood flow in patients with chronic congestive heart failure: Evidence of "forward failure" as the primary cause of edema. J. Clin. Invest., 1946, 25, 389.
5. Stead, E. A., Jr., Warren, J. V., and Brannon, E. S., Cardiac output in congestive heart failure. Am. Heart J., 1948, 35, 529.

6. Brannon, E. S., Merrill, A. J., Warren, J. V., and Stead, E. A., Jr., The cardiac output in patients with chronic anemia as measured by the technique of right atrial catheterization. J. Clin. Invest., 1945, 24, 332.

7. Myers, J. D., and Holland, B. C., Unpublished observations.

8. Dock, W., The role of increased hepatic arterial flow in the portal hypertension of cirrhosis. $\mathrm{Tr}$. A. Am. Physicians, 1942, 57, 302.

9. Warren, J. V., Stead, E. A., Jr., and Brannon, E. S., The cardiac output in man: A study of some of the errors in the method of right heart catheterization. Am. J. Physiol., 1946, 145, 458.

10. Rich, A. R., The pathogenesis of the forms of jaundice. Bull. Johns Hopkins Hosp., 1930, 47, 338.

11. Hickam, J. B., and Cargill, W. H., Effect of exercise on cardiac output and pulmonary arterial pressure in normal persons and in patients with cardiovascular disease and pulmonary emphysema. J. Clin. Invest., 1948, 27, 10. 